\title{
EQUIVALENT FRAME METHOD COMBINING FLEXURAL AND SHEAR RESPONSES OF MASONRY BUILDINGS
}

\author{
C. MARANO ${ }^{*}$, M. PETRACCA ${ }^{2}$, G. CAMATA ${ }^{1}$ AND E. SPACONE $^{1}$ \\ ${ }^{1}$ Università degli Studi G. d'Annunzio Chieti e Pescara \\ Department of Engineering and Geology (InGeo) \\ ${ }^{2}$ ASDEA Software \\ Via Breveglieri, 8 - 65128 Pescara, Italy \\ web: http://asdeasoft.net
}

Keywords: Masonry, Pushover Analysis, Equivalent frame, Fiber elements, Vulnerability

\begin{abstract}
This work presents the results of quasi-static non-linear analyses of two masonry buildings using, for the discretization of walls, a macro-element that combines the bending and the in-plane shear responses. The macro-element uses the force-based beamcolumn element equipped with cross sections discretized in fibers, where the behavior of each fiber is described by uniaxial constitutive models. To describe the shear response of the structural element, the macro-element embeds a shear hinge at mid-span, with a phenomenological non-linear constitutive model calibrated on experimental data. The analyzed buildings are two tangibles examples of un-reinforced and reinforced masonry of the Italian Heritage. The un-reinforced masonry building is a strategic building monitored by the O.S.S., partially damaged by the seismic events in Center Italy in 2016. The reinforced masonry building, a three-storey residential structure, is subject of evaluations carried out in the ReLuis RINTC project, designed as per D.M. 2018.
\end{abstract}

\section{INTRODUCTION}

The seismic events which recently struck the Italian Peninsula have shown the limited earthquake performance of existing masonry structures.

Their high vulnerability is linked to various sources of weakness such as very disparate construction typologies, buildings remodeled over time with interventions without criteria, absence of structural design, architectural modifications, interventions without adequate structural evaluation: most of the existing buildings in masonry are therefore not designed to transfer seismic forces from horizontal to vertical elements.

Nonlinear numerical simulations of existing masonry buildings still represent an open problem in research because it is difficult to develop reliable numerical models of real buildings.

This study presents the results of non-linear pushover analyzes performed on two unreinforced and reinforced masonry buildings. The method, called equivalent frame method (EFM), uses one-dimensional nonlinear macroelements connected through nodal panels considered to be nondeformable and rigid. 
The macroelement, originally developed for reinforced concrete structures [1], has been extended in previous works $([2,3,4,5])$ to the static and dynamic nonlinear analysis of masonry structures. The macroelement consists of Force Based Elements (FBE) ([6,7]) combined with nonlinear lumped hinges.

The equilibrium between moment and shear is guaranteed at the element level; if properly calibrated, the macroelement is particularly effective in simulating the in plane and out-of-plane response of wall panels of ordinary and reinforced masonry buildings.

The equivalent frame model is implemented in the open source computational platform OpenSees 3.0.3 3 ([8]) with which the numerical analyzes will be conducted together with the pre and post-processor Scientific ToolKit for Opensees, STKO ([9]).

\section{EQUIVALENT FRAME METHOD WITH FIBER BASED ELEMENTS AND PHENOMENOLOGICAL LUMPED HINGES}

In the simplified approach with EFM, the masonry structures are modeled by assembling equivalent vertical and horizontal one-dimensional elements: piers and spandrels are modeled with appropriate constitutive laws and connected to each other through rigid areas (Figure 1).
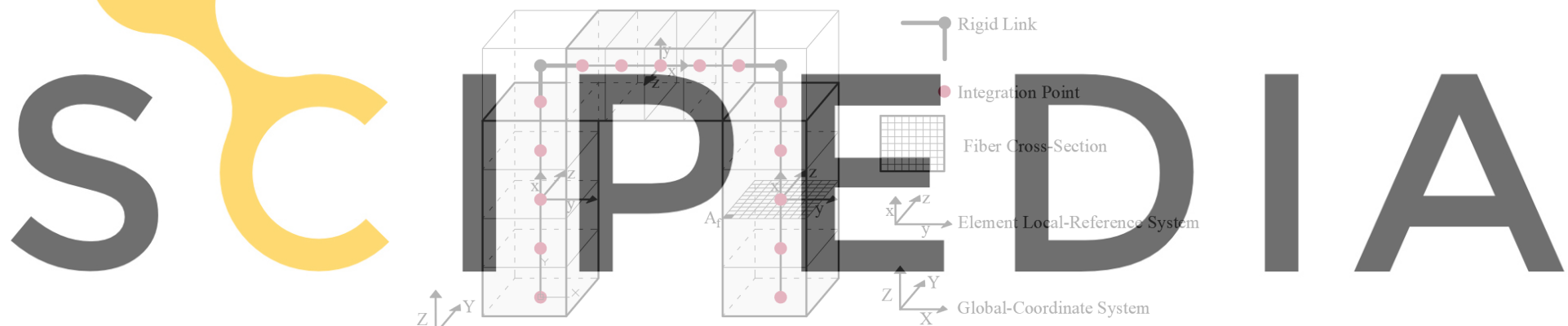

Register for free at https//WwW.scipedia.com to download the version without the watermark

Figure 1: EFM discretization

The interaction between axial and flexural behavior is captured by the macroelement using force based fiber elements (Figure 2). The diagonal and sliding shear behavior is captured with a phenomenological law. Flexure and shear interaction is ensured with the equilibrium along the element (Figure 3).

For the unreinforced masonry (URM) building behavior, the uniaxial material "Concrete02" (OpenSees 3.0.3) is used to simulate the masonry. The tensile strength is assumed to be 1/30 of the compressive strength.

For the reinforced masonry (RM) buildings, the masonry behavior is modeled with the uniaxial material "Concrete01" with zero tensile strength an steel bar behavior is modeled with the uniaxial bilinear steel Material "Steel01".

The uniaxial multilinear material of OpenSees 3.0.3 is used to simulate the shear behavior of the wall panels. 

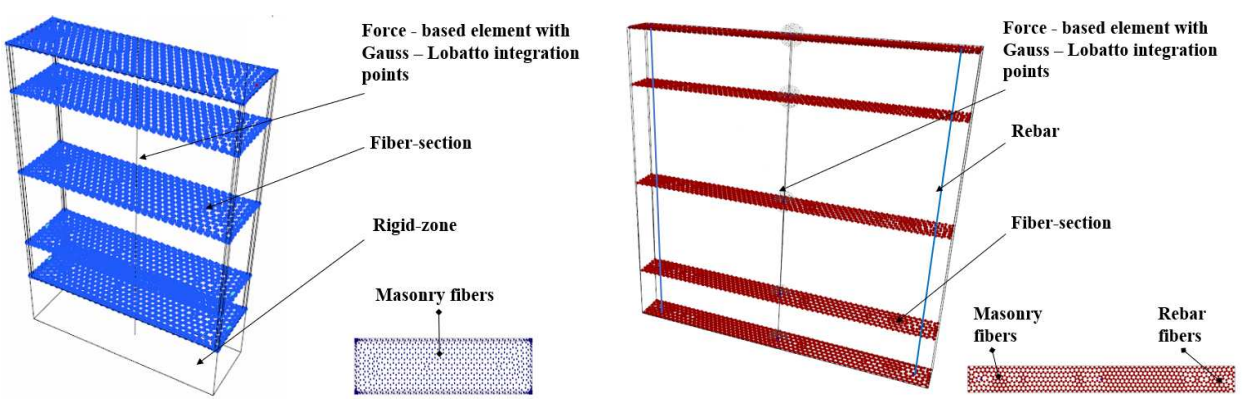

Figure 2: Macroelement formulation

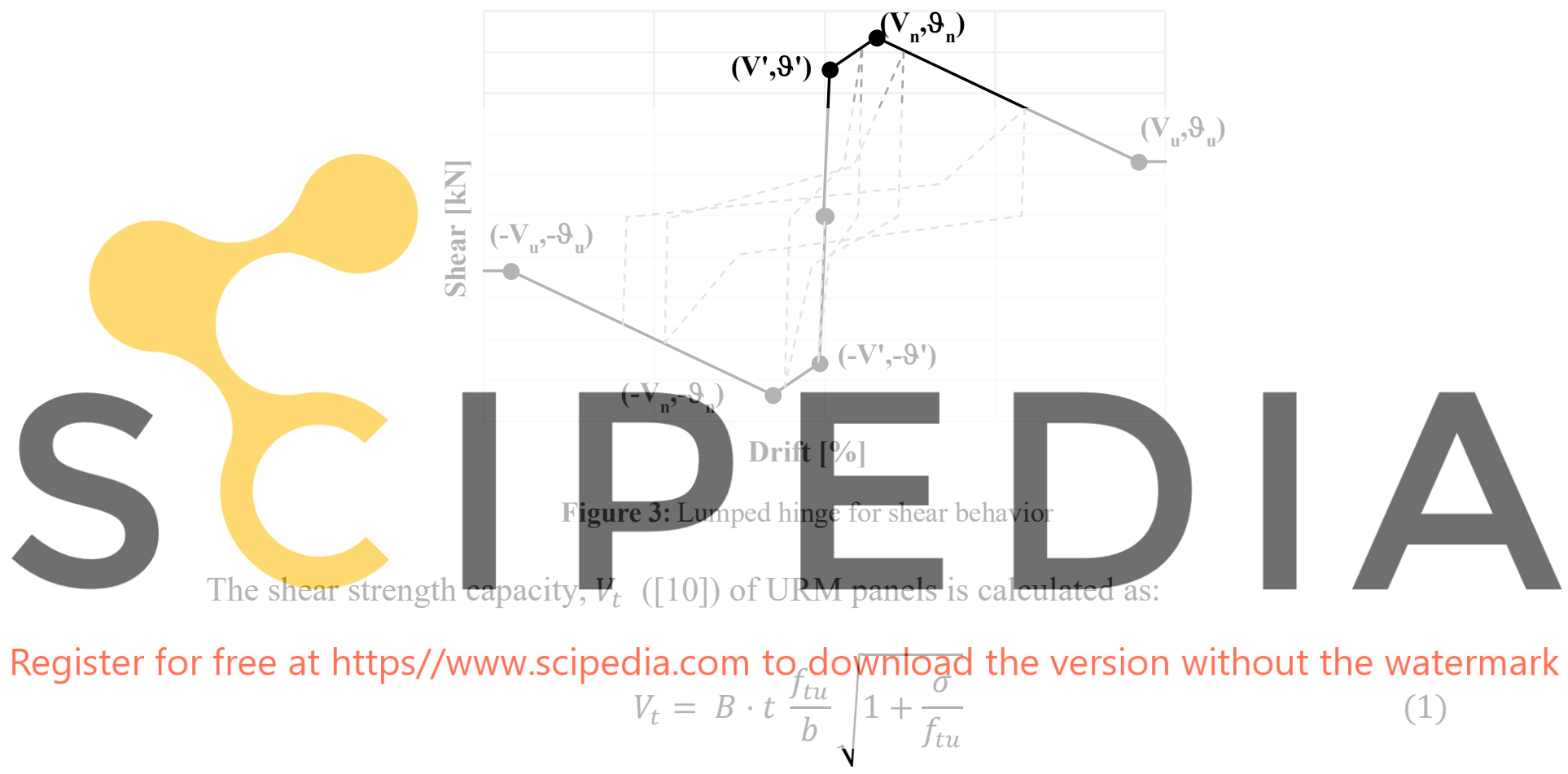

where:

$f_{t u}$ is the masonry tensile strength;

$b$ is equal to 1.5 ;

$B$ and $t \mathrm{t}$ are the length and thickness of the panel, respectively.

The shear strength Vt ([11]) of the RM panels is calculated as the sum of the contributions of the masonry shear capacity $V_{t, M}$ and the reinforcement capacity $V_{t, s}$, according to the following relationships:

$$
\begin{aligned}
& V_{t}=V_{t, M}+V_{t, S} \\
& V_{t, M}=d \cdot t \cdot f_{v d}
\end{aligned}
$$

where: 
$d$ is the distance between the extreme compressed fiber and the center of tensile reinforcement;

$t$ is the panel thickness;

$f_{v d}$ is the shear strength of the masonry under compression.

$$
V_{t, s}=\left(0.6 \cdot d \cdot A_{s w} \cdot f_{v d}\right) / s
$$

where:

$A_{s w}$ shear strengthening area in the direction of the shear forces

$f_{v d}$ steel design yielding strength;

$s$ spacing among the transversal reinforcement.

In deformation terms, the ultimate angular deformation, $\vartheta_{u}$ of URM panels (URM) at the life safety limit state is assumed to be equal to $0.4 \%$ of the panel height [12]; in the case of RM panels, the ultimate angular deformation, $\vartheta_{u}$ is assumed to be $0.6 \%$ of the height of the panel [12].

The shear phenomenological law considered in this study does not depend on the axial load $\mathrm{N}$; once the parameters have been set, the law remains constant during the analysis.

The ultimate bending moment, $M_{u}$ of the masonry spandrels, as indicated in the Italian code DM 2018 [11] is calculated as:

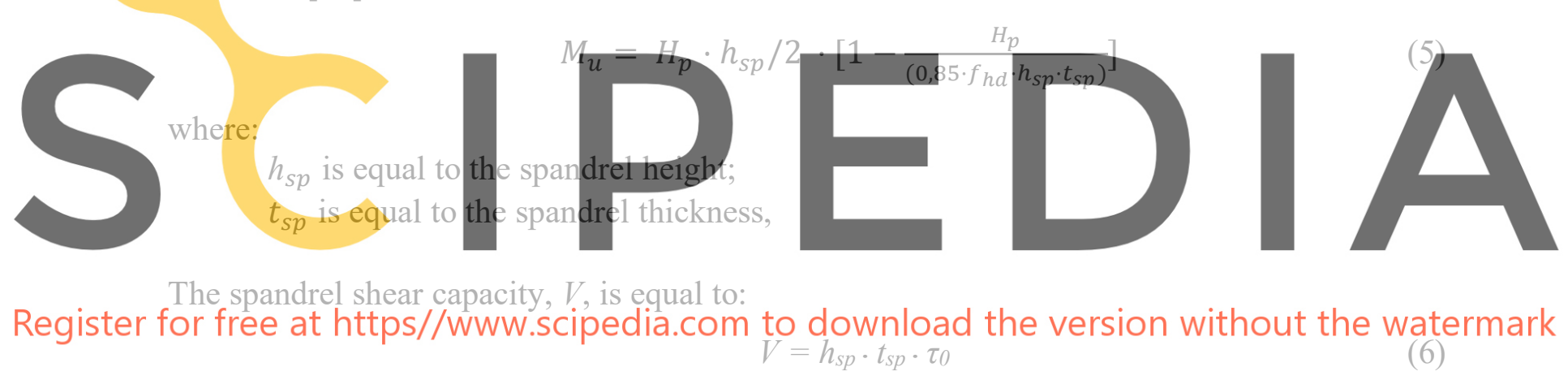

where:

$\tau_{0}$ masonry shear strength;

$h_{s p}$ masonry spandrel height;

$t_{s p}$ masonry spandrel thickness.

\section{PUSH OVER ANALYSES OF TWO LARGE UNREINFORCED AND REINFORCED MASONRY BUILDINGS}

\subsection{Description of the building investigated}

The first case study presented in this work is a pushover analysis conducted on the "Pietro Capuzi" kindergarten school in Visso - Marche - MC - Italy; this is an URM building monitored by the Seismic Observatory on Structures [13] which during the last Italian seismic events (Central Italy - 2016) suffered serious structural damage $([14,15])$. 
The chosen structure is characterized by a regular distribution of the openings and a predominantly global response with localized damage in the piers and in the masonry spandrels, which can be modeled well with EFM. The plan building was asymmetrical in the two main directions (longitudinal X, transversal Y) and consisted of a mezzanine and a first floor (Figure 4).
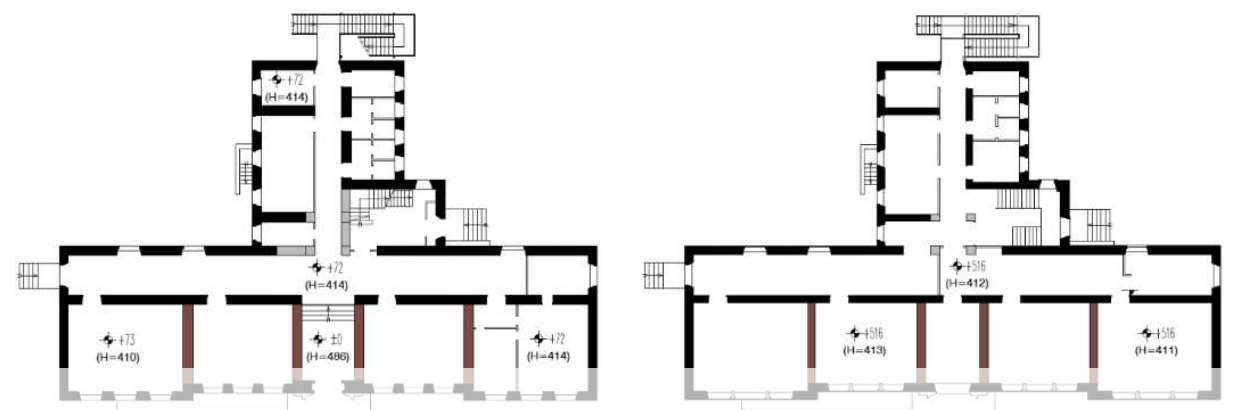

Figure 4: First and second floor plan

The building, as shown in Figure 5, had several cracks caused by in-plane failure mechanism of the piers and spandrels, damage to the infills and non-load-bearing structures ([16]).
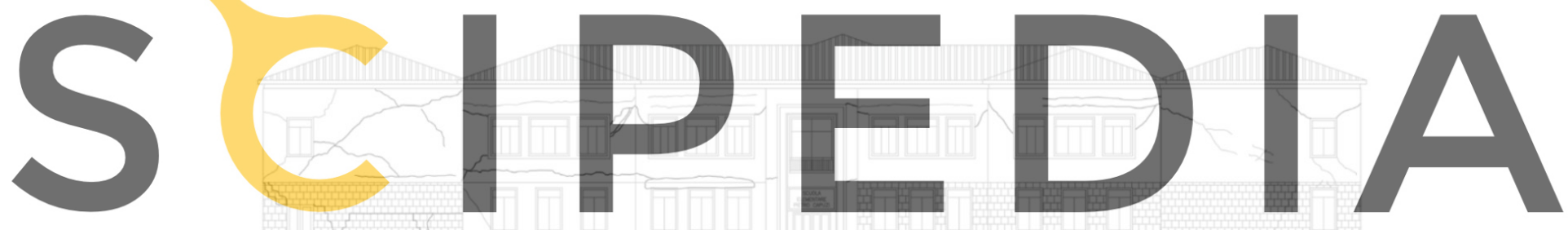

Register for free at https//www.scipedia.com to download the version without the watermark

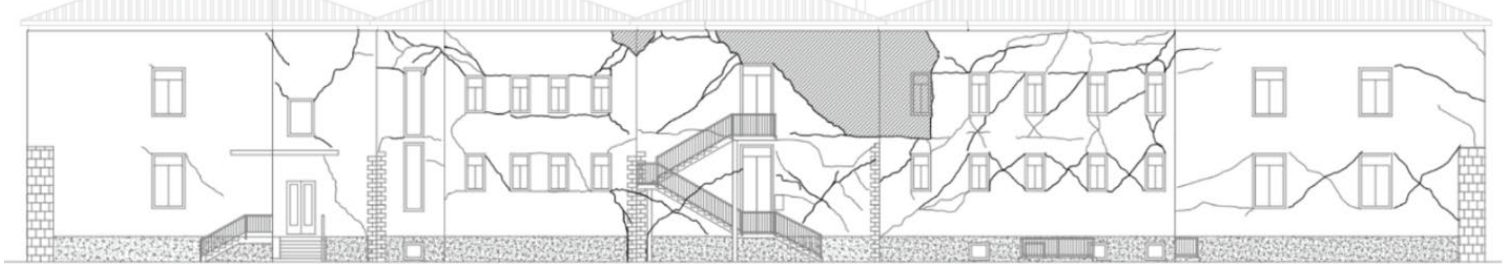

Figure 5: Observed damage, adapted from [16]

The second case study presented in this paper is an archetypal building in RM called in this work E8 and calculated according to the Italian design code [17].

The objective of the pushover on the E8 building is to evaluate, through the simplified macroelement model, the building seismic performance as well as detect the damage in the panels and in the steel rebars. The building (Figure 6), designed for L'Aquila (Italy) on type C soil and topography [11] has an axis of symmetry in the direction $\mathrm{Y}$, the height between floors is $3.10 \mathrm{~m}$ and slab depth equal to $0.25 \mathrm{~m}$ on all levels. All slabs are unidirectional. The wall thickness of the external walls is $0.30 \mathrm{~m}$ and of the internal ones is $0.25 \mathrm{~m}$. 


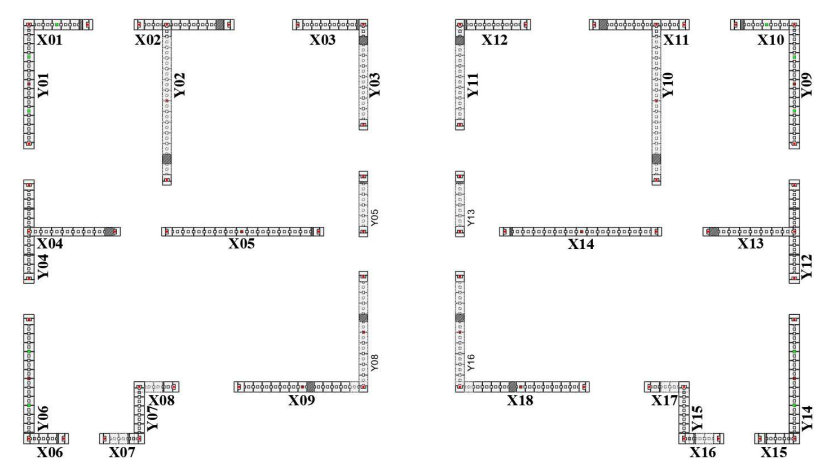

Figure 6: Plan of the E8 building

\subsection{Numerical models}

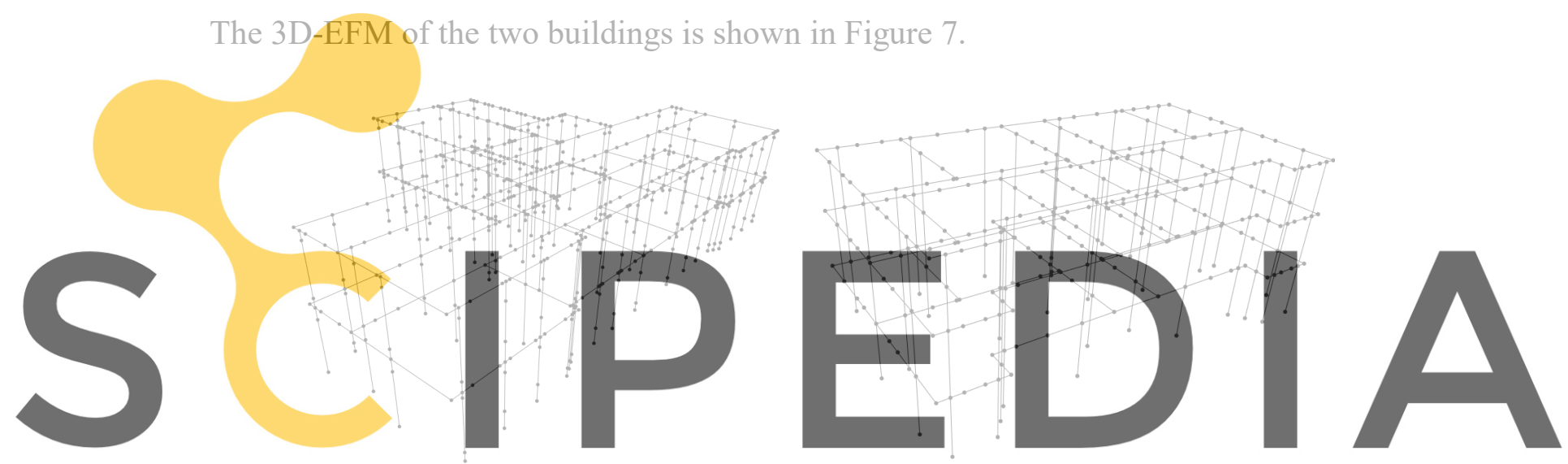

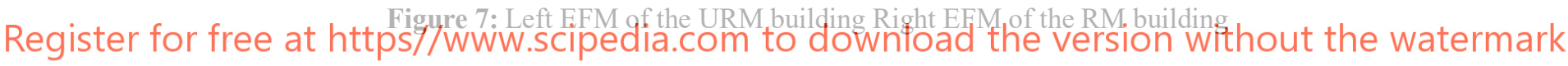

The numerical model of the URM building considers the height of the piers and the length of the panels according to the method proposed by [18].

The mezzanine floor $(+4.30 \mathrm{~m})$ and the first floor $(+8.70 \mathrm{~m})$ are modeled, while the basement is not considered in the model. The roof and the attic floor are not explicitly modeled but their contribution is taken into account in terms of masses and gravity loads. The curbs are modeled explicitly, while the floors are idealized with kinematic constraints as rigid diaphragms. The piers and the spandrels have a rectangular cross section and the structure is assumed fixed at the base.

The numerical model of the RM building considers the height of the piers equal to the height of the floors. The ground floor $(+3.00 \mathrm{~m})$, the first floor $(+6.00 \mathrm{~m})$ and the roof $(+9.00 \mathrm{~m})$ are modeled. The RC curbs are assumed to behave linearly elastic. The corner reinforcement bars, which are in common with two orthogonal piers, have been distributed equally between the piers considering for each pier a $8 \mathrm{~mm}$ diameter bar, the other bars have a diameter of $16 \mathrm{~mm}$. The weight of the elements in both models is applied as distributed load transmitted from the floors to the structural elements.

Table 1 and Table 2 show the mechanical properties assigned to the fiber model: masonry 
compressive strength, $f_{m}$, masonry tensile strength, $f_{t u}$, masonry shear strength, $f_{v m 0}$, Elastic Modulus, $E_{m}$, Shear Modulus, $G$, masonry specific weight, $W$, and steel bar yielding strength, $f_{y m}$.

Table 1: URM material parameters

\begin{tabular}{ccccc}
\hline$f_{m}$ & $f_{t u}$ & $E_{m}$ & $G$ & $W$ \\
\hline $\mathrm{N} / \mathrm{mm}^{2}$ & $\mathrm{~N} / \mathrm{mm}^{2}$ & $\mathrm{~N} / \mathrm{mm}^{2}$ & $\mathrm{~N} / \mathrm{mm}^{2}$ & $\mathrm{kN} / \mathrm{m}^{2}$ \\
\hline 4.8 & 0.14625 & 2610 & 870 & 21.00 \\
\hline
\end{tabular}

Table 2: RM material parameters

\begin{tabular}{cccccc}
\hline$f_{m}$ & $f_{v m 0}$ & $E_{m}$ & $G$ & $W$ & $f_{y m}$ \\
\hline $\mathrm{N} / \mathrm{mm}^{2}$ & $\mathrm{~N} / \mathrm{mm}^{2}$ & $\mathrm{~N} / \mathrm{mm}^{2}$ & $\mathrm{~N} / \mathrm{mm}^{2}$ & $\mathrm{kN} / \mathrm{m}^{2}$ & $\mathrm{~N} / \mathrm{mm}^{2}$ \\
\hline 6.436 & 0.2857 & 5300 & 2120 & 9.00 & 483.871 \\
\hline
\end{tabular}

For both buildings, pushover analysis are performed using displacement control according to a distribution of forces proportional to the masses and using as target displacement a node on the top floor of both buildings. In each step, equilibrium is achieved with a Krylov-Newton iteration process and convergence is accepted with a residual tolerance of $1 \times 10^{-5}$.

\subsection{URM results}

Figure 8 shows the indications in [18]. The displacement of 22.30 diagonal cracking failu In the longitudinal dire squat wall panels fail in shear. The analysis is
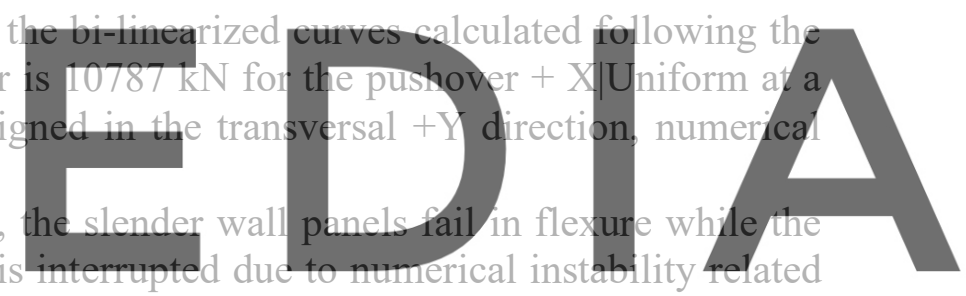

to the brittle failures of the masonry walls on the mezzanine floor.

Register for free at https//www.scipedia.com to download the version without the watermark

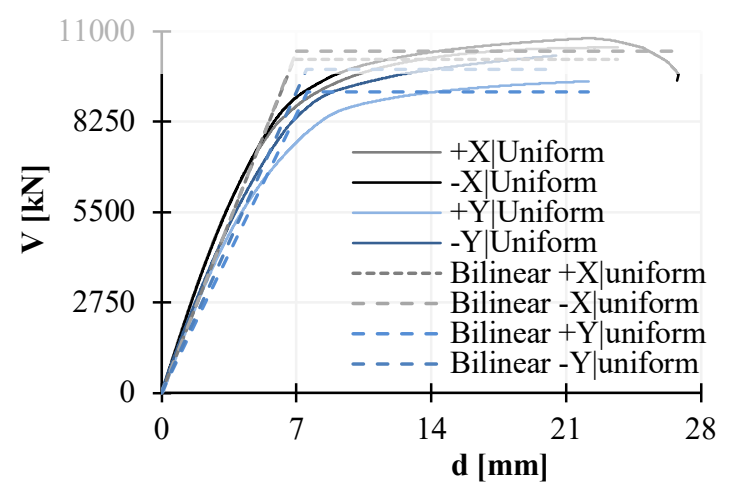

Figure 8: URM capacity curves and bilinearizations

Figure 9 compares the bi-linearized curves and the Acceleration-Displacement Response Spectrum (ADRS), evaluated considering a subsoil Type D category with topography T1 [11].

The seismic risk indicator, $\zeta_{\mathrm{E}}$, defined as the ratio between the capacity and the demand, calculated for the four capacity curves is equal to $0.365,0.416,0.346$ and 0.281 for the 
distribution $+\mathrm{X} \mid$ Uniform, $-\mathrm{X} \mid$ Uniform, $+\mathrm{Y} \mid$ Uniform and $-\mathrm{Y} \mid$ Uniform, respectively. The curves show that the structure has a very limited capacity and it is prone to damage under cyclic loads induced by the earthquake.

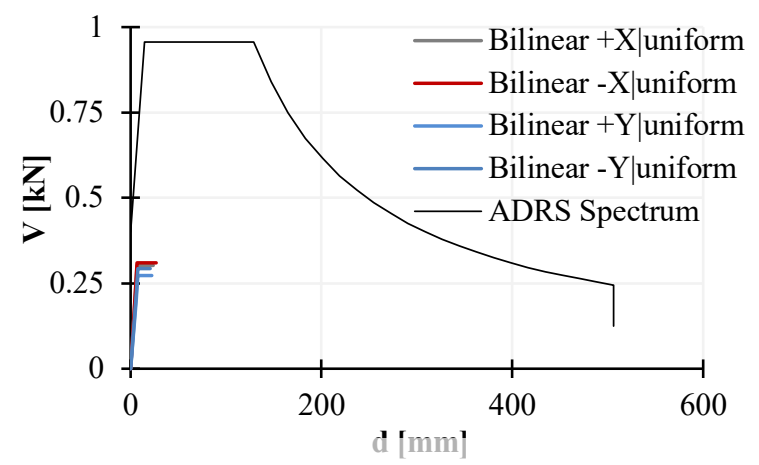

Figure 9: URM Demand vs Capacity URM

Figure 10 shows the comparison between the actual damage observed on site on wall 4 and the numerical damage simulated with OpenSees. The panels at the mezzanine level failed in shear and the wall at the first floor failed because of mixed flexure-shear mechanisms.

Damage is also observed in the spandrels on the mezzanine and first floors. The lumped hinge behavior, $V-\delta_{4}$ extrapolated at the base of the piers highights a shear nunner ical failure predicting correctly the ultimate drift, while the

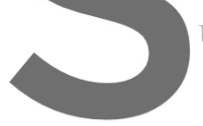

ultimate drift). The num
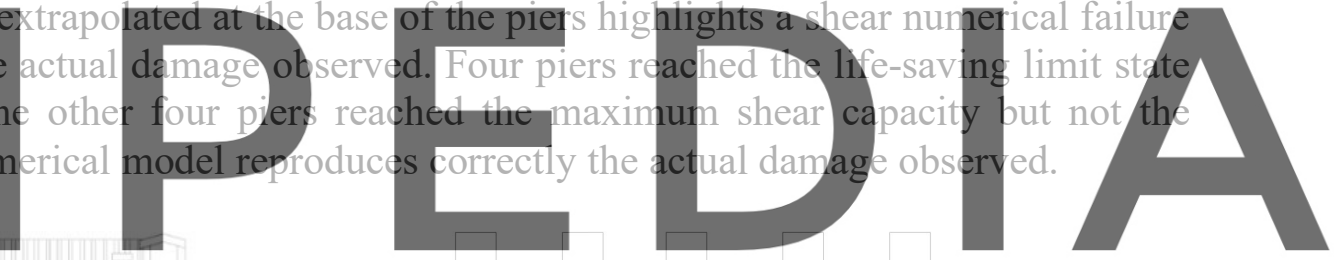

Register for free at https/fwww.scipedia.com to download the vẹrsion: without the watermark
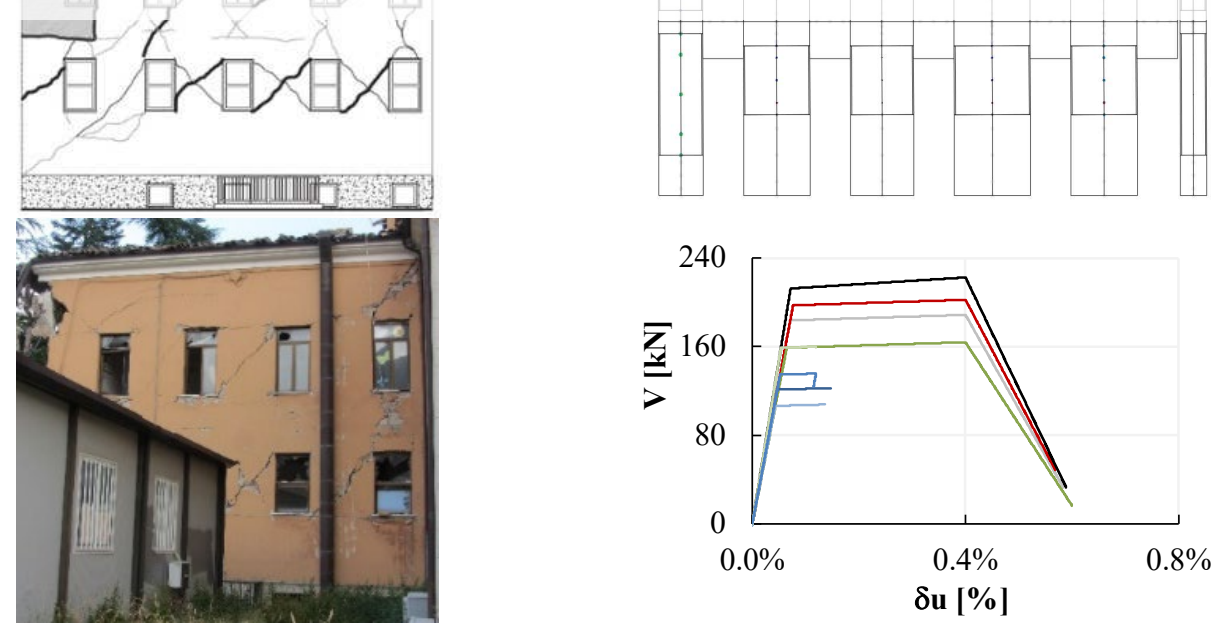

Figure 10: Comparison between numerical and observed damage - wall $n^{\circ} 4$ 


\subsection{RM results}

Figure 11 shows the four capacity curves and the relative bi-linearized curves obtained for the RM building. The maximum base shear capacity is $7415.13 \mathrm{kN}$ for the pushover + Y|Uniform at a horizontal displacement equal to $39.68 \mathrm{~mm}$. The comparison shows an overlap of the curves in the longitudinal direction $\mathrm{X}$ due to the perfect symmetry of the building in the direction orthogonal to it. The building collapse is triggered by the panel shear failures on the ground floor in both directions of analysis.

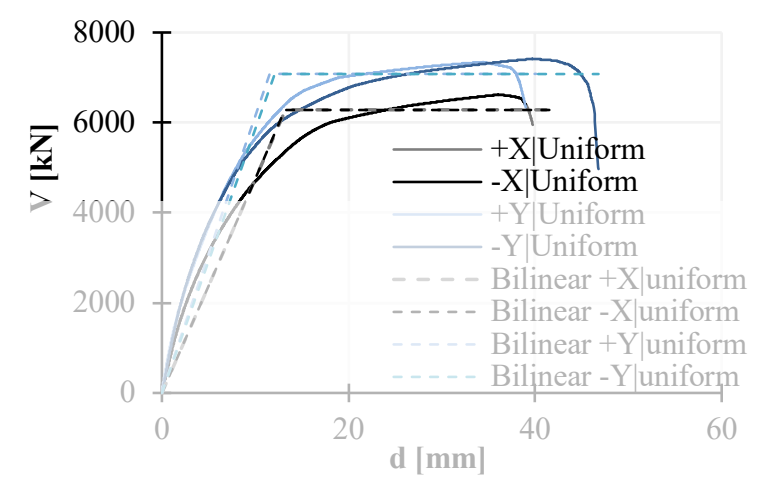

\section{Figure 11: RM capacity curves and bilinearizations}

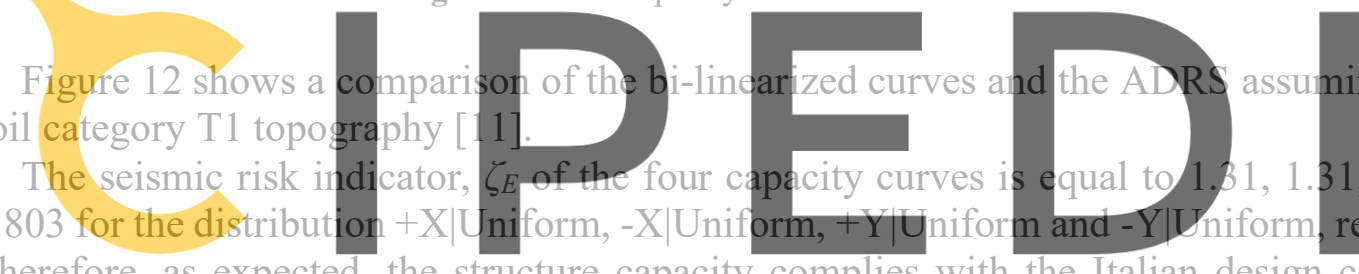

Therefore, as expected, the structure capacity complies with the Italian design codes, D.M.

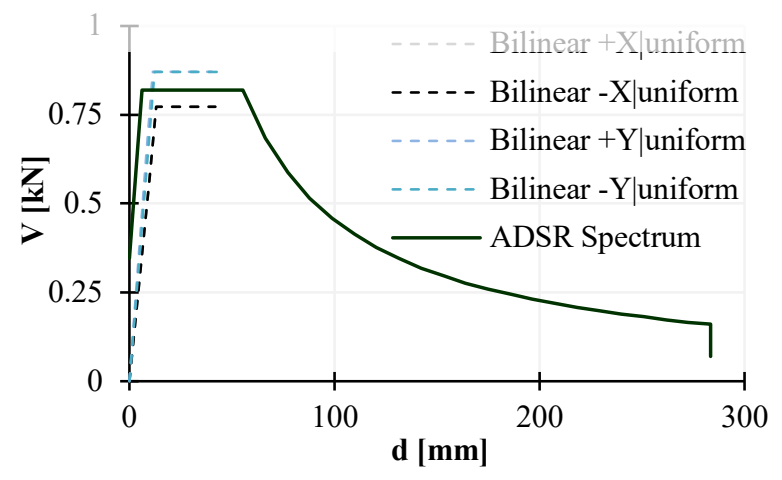

Figure 12: Demand vs Capacity RM

Figure 13 shows, the steel fiber behavior of panel X06 and the Gauss point behavior of panel $\mathrm{X} 14$ for the force distribution proportional to the masses in the positive longitudinal direction, $+\mathrm{X} \mid$ Uniform. 

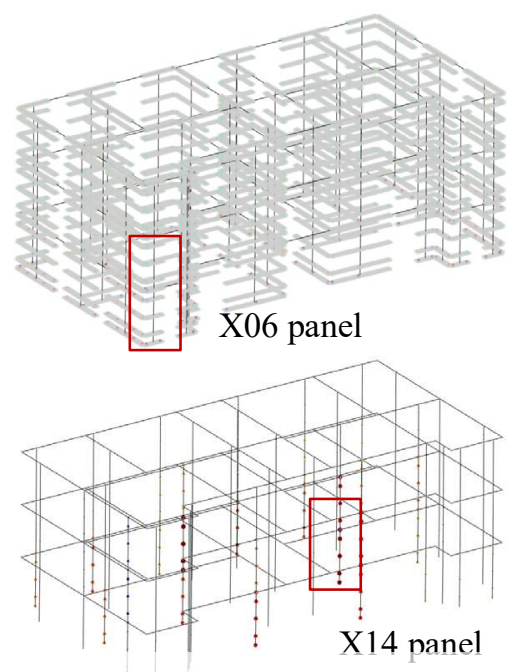
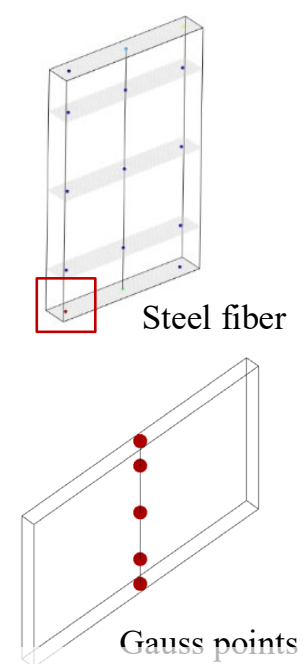

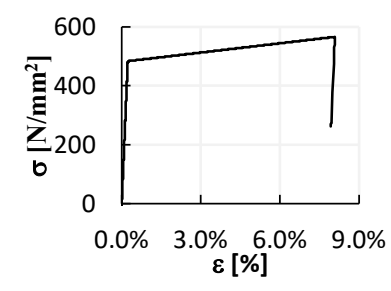

Steel fiber stress-strain curve

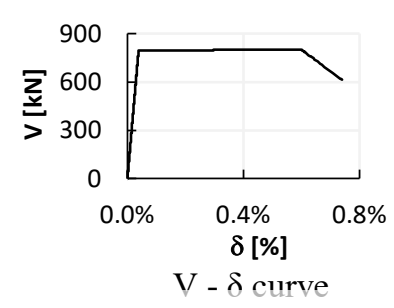

Figure 13: Numerical damage of panel and bars

The results show that the pier on the corner at the ground floor yields because of bar yielding, however the building collapses because of shear failure as indicated by the gauss points.

4 CONCLUSIONS

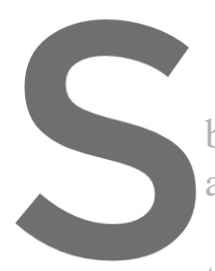

This work presents the results of pushover
uildings. The models are developed using the
FBEs are used to describe the axial-bending

to simulate the shear behavior.
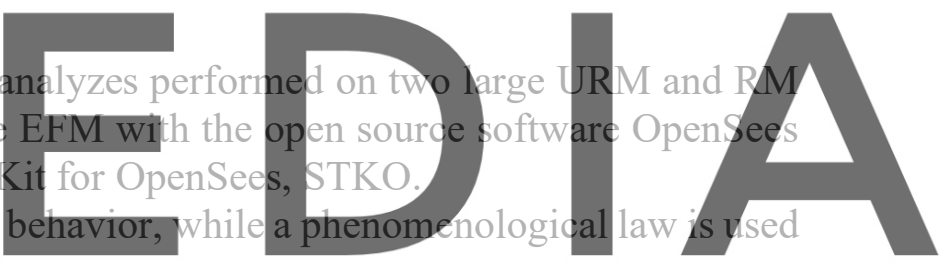

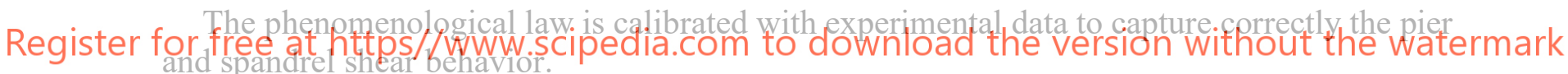

In both case studies, URM and RM, the capacity curves are compared with the demands.

The results of the analyses on the URM building show that the model is capable to describe correctly the damage occurred and that the URM building is highly vulnerable.

The RM building behaves well under seismic load, the seismic risk $\zeta_{E}$ is higher than 1.31 and therefore the building design complies with the Italian design codes. The EFM proposed in this work ensures to consider correctly the biaxial-bending interaction and to evaluate in depth the steel bar behavior and damage. The quality of the results obtained can be further improved by considering the variation of the axial load to describe the pier shear behavior.

Despite convergence problems that can occur in quasi-brittle materials with softening and the limitations due to the phenomenological shear law, the EFM proposed in this work is particularly efficient and accurate for the non-linear analysis of large-scale masonry structures.

\section{REFERENCES}

[1] Marini, A., and Spacone, E. Analysis of reinforced concrete elements including shear effects. ACI Structural Journal, 2006, 103.5: 645. 
[2] Raka, E., Spacone, E., Sepe, V., and Camata, G. Advanced frame element for seismic analysis of masonry structures: model formulation and validation. Earthquake Engineering \& Structural Dynamics, 2015, 44.14: 2489-2506.

[3] Siano, R., Sepe, V., Camata, G., Spacone, E., Roca, P., and Pelà, L. Analysis of the performance in the linear field of equivalent-frame models for regular and irregular masonry walls. Engineering Structures, 2017, 145: 190-210.

[4] Siano, R., Roca, P., Camata, G., Pelà, L., Sepe, V., Spacone, E., and Petracca, M. Numerical investigation of non-linear equivalent-frame models for regular masonry walls. Engineering Structures, 2018, 173: 512-529.

[5] Peruch, M., Spacone, E., and Camata, G. Nonlinear analysis of masonry structures using fiber-section line elements. Earthquake Engineering \& Structural Dynamics, 2019, 48.12: $1345-1364$.

[6] Spacone, E., Filippou, F. C., and Taucer, F. F. Fibre beam-column model for non-linear analysis of R/C frames: Part I. Formulation. Earthquake Engineering \& Structural Dynamics, 1996, 25.7: 711-725.

[7] Spacone, E., Filippou, F. C., and Taucer, F. F. Fibre beam-column model for non-linear analysis of R/C frames: part II. Applications. Earthquake Engineering \& Structural Dynamics, 1996, 25.7: 727-742.

[8] Mazzoni, S., McKenna, F., Scott, M. H., and Fenves, G. L. OpenSees command language manual. Pacific Earthquake Engineering Research (PEER) Center, 2006, 264.

[9] Petracca, M., Candeloro, F., and Camata, G. "STKO user Manual”. ASDEA Software Tecnology, 2019, Pescara Italy.

[10] Turnšek, V., and Čačovič, F. (1971, December). Some experimental results on the strength of brick masonry walls. In: Proc. of the 2nd International Brick Masonry Conference. 1971. p. 149-156.

[11] Aggiornamento delle Norme Tecniche per le Costruzioni (NTC2018). Ministero delle Infrastrutture e dei Trasporti: Rome, Italy.

[12] Circolare esplicativa 21/01/2019 n. 7. Istruzioni per l'applicazione dell' «Aggiornamento delle "Norme tecniche per le costruzioni"». DM 17/01/2018 [In Italian].

[13] Dolce, M., Nicoletti, M., De Sortis, A., Marchesini, S., Spina, D., and Talanas, F. Osservatorio sismico delle strutture: the Italian structural seismic monitoring network. Bulletin of Earthquake Engineering, 2017, 15.2: 621-641.

[14] Cattari, S., Degli Abbati, S., Ottonelli, D., Marano, C., Camata, G., Spacone, E., ... and Penna, A. Discussion on data recorded by the Italian structural seismic monitoring network on three masonry structures hit by the 2016-2017 Central Italy earthquake. Proc. of COMPDYN, 2019.

[15] Cattari, S., Degli Abbati, S., Ottonelli, D., Sivori, D., Spacone, E., Camata, G., ... and Graziotti, F. Task 4.1 Workgroup_Report di sintesi sulle attività svolte sugli edifici in 
muratura monitorati dall'Osservatorio Sismico delle Strutture, Linea Strutture in Muratura. ReLUIS Report, Rete Dei Laboratori Universitari Di Ingegneria Sismica, 2017.

[16] Cattari, S., Sivori, D. "Relazione tecnica scuola dell' infanzia Pietro Capuzi” (in italian), 2016.

[17] Iervolino, I., Spillatura, A., and Bazzurro, P. RINTC project: assessing the (implicit) seismic risk of code-conforming structures in Italy. COMPDYN, 2017.

[18] Lagomarsino, S., Penna, A., Galasco, A., and Cattari, S. TREMURI program: an equivalent frame model for the nonlinear seismic analysis of masonry buildings. Engineering structures, 2013, 56: 1787-1799. 